\title{
Pacjent z nadciśnieniem tętniczym i hipercholesterolemią - czy możemy być skuteczniejsi w leczeniu?
}

\author{
Patient with arterial hypertension and hypercholesterolaemia \\ - can we be more effective in treatment?
}

\author{
Iwona Gorczyca-Michta ${ }^{1}$, Beata Wożakowska-Kapłon ${ }^{1,2}$ \\ ${ }^{1}$ I Klinika Kardiologii i Elektroterapii Świętokrzyskiego Centrum Kardiologii w Kielcach \\ ${ }^{2}$ Wydział Lekarski i Nauk o Zdrowiu Uniwersytetu Jana Kochanowskiego w Kielcach
}

\section{Streszczenie}

Nadciśnienie tętnicze i dyslipidemia to najczęściej występujące czynniki ryzyka sercowo-naczyniowego, które często ze sobą współistnieją. Skuteczność leczenia nadciśnienia tętniczego i dyslipidemii nadal jest niezadowalająca. Zastosowanie złożonej terapii hipotensyjnej i hipolipemizującej poprawia wyniki leczenia nadciśnienia tętniczego i hipercholesterolemii.

Słowa kluczowe: nadciśnienie tętnicze, dyslipidemia, terapia złożona

Folia Cardiologica 2017; 12, 3: 262-270

\section{Epidemiologia nadciśnienia tętniczego i hipercholesterolemii - jak często schorzenia współistnieją ze sobą?}

Nadciśnienie tętnicze i hipercholesterolemia to schorzenia cywilizacyjne. Odpowiednia kontrola wymienionych czynników ryzyka sercowo-naczyniowego jest istotna ze względu na możliwość redukcji ryzyka zgonu i zachorowalności na choroby układu krążenia. Szacuje się, że w Polsce odsetek przedwczesnej umieralności, czyli zgonów osób w wieku 25-64 lat spowodowanych chorobami układu sercowo-naczyniowego jest ponad 2-krotnie wyższy niż w innych krajach Unii Europejskiej [1].

Nadciśnienie tętnicze dotyka ponad 20\% mieszkańców krajów wysokorozwiniętych. W Stanach Zjednoczonych, według danych National Health and Nutrition Examination Survey (NHANES), nadciśnienie tętnicze występuje u 33,5\% dorosłej populacji [2]. W Wielkiej Brytanii odsetek chorujących na nie osób jest wyższy i wśród osób między 35. a 64. rokiem życia wynosi 42\% [3]. Liczba pacjentów chorujących na nadciśnienie tętnicze w Polsce jest wyższa o $2 \%$ niż 10 lat temu. Obecnie choruje około 32\% dorosłych Polaków (10,5 mln chorych, w tym 9,5 mln w wieku 18-79 lat i prawie $\mathrm{mln}$ u osób > 80 lat). Aż $3 \mathrm{mln}$ Polaków nie uświadamia sobie, że chorują [4]. Częstość występowania nadciśnienia tętniczego istotnie wzrasta z wiekiem. Odsetek chorych na nadciśnienie w wieku emerytalnym jest wyższy niż w populacji ogólnej i wynosi 58\%. W badaniu WOBASz wykazano wyższy niż w badaniu NATPOL III PLUS odsetek chorych na nadciśnienie tętnicze wynoszący 36\% [5]. Rozpoznanie to częściej dotyczyło mężczyzn niż kobiet (42,1\% v. 32,9\%) [5].

Hipercholesterolemia jest najczęściej występującym czynnikiem ryzyka sercowo-naczyniowego. W badaniu NHANES hipercholesterolemię, definiowaną jako stężenie cholesterolu całkowitego (TC, total cholesterol) większe lub równe $200 \mathrm{mg} / \mathrm{dl}$, stwierdzono u 50,9\% kobiet oraz 50,4\% mężczyzn [6]. W populacji niemieckiej odsetek osób ze stężeniem TC ponad 190 mg/dl był nieco wyższy; wynosił

Adres do korespondencji: dr n. med. Iwona Gorczyca-Michta, I Klinika Kardiologii i Elektroterapii, Świętokrzyskie Centrum Kardiologii,

ul. Grunwaldzka 45, 25-736 Kielce, e-mail: iwona.gorczyca@interia.pl 
60,5\% u kobiet oraz 56,5\% u mężczyzn [7]. Według danych z badania NATPOL 2011 hipercholesterolemia, definiowana jako stężenie TC większe lub równe $190 \mathrm{mg} / \mathrm{dl}$ albo stosowanie leków hipolipemizujących, w polskiej populacji występowała u 61,1\% badanych (w tym u 60,8\% mężczyzn i $61,3 \%$ kobiet), a gdy definicję hipercholesterolemii oparto tylko na stężeniu cholesterolu odsetek ten wynosił 54,3\% [8]. Częstość występowania dyslipidemii, podobnie jak nadciśnienia tętniczego, istotnie zwiększała się z wiekiem i była najwyższa w grupie osób w wieku 60-79 lat - 82,9\%. Częstość występowania zwiększonego stężenia cholesterolu frakcji lipoprotein o niskiej gęstości (LDL, low-density lipoprotein) (definiowanego jako $\geq 115 \mathrm{mg} / \mathrm{dl}$ ) wśród wszystkich badanych wynosiła 57,8\% (58,3\% u mężczyzn oraz 57,3\% u kobiet). Natomiast stężenie cholesterolu frakcji lipoprotein o wysokiej gęstości (HDL, high-density lipoprotein), poniżej $40 \mathrm{mg} / \mathrm{dl}$ zanotowano u 35,2\% mężczyzn, a mniejsze niż $45 \mathrm{mg} / \mathrm{dl}-\mathrm{u} 22,2 \%$ kobiet. Hipertriglicerydemia (stężenie TG $\geq 150 \mathrm{mg} / \mathrm{dl}$ ) występowała u $21,1 \%$ badanych (28,4\% mężczyzn oraz $14,0 \%$ kobiet). Średnie stężenie TC u mężczyzn wynosiło 197,1 mg/dl, natomiast u kobiet - 198,6 mg/dl, stężenie cholesterolu frakcji LDL, odpowiednio, 123,6 mg/dl i 123,7 mg/dl, stężenie cholesterolu frakcji HDL, odpowiednio, $45,8 \mathrm{mg} / \mathrm{dl}$ i $54,1 \mathrm{mg} / \mathrm{dl}$, a stężenie TG, odpowiednio, $140,9 \mathrm{mg} / \mathrm{dl}$ i $104 \mathrm{mg} / \mathrm{dl}$ [8].

Nadciśnienie tętnicze i dyslipidemia są najczęściej występującymi oraz współistniejącymi czynnikami ryzyka sercowo-naczyniowego. Badaniem POSTER przeprowadzonym w 2013 roku objęto 42338 chorych z nadciśnieniem tętniczym, a niedostateczną kontrolę ciśnienia stwierdzono u 54,3\%, których poddano dalszej analizie. U większości chorych z niedostateczną kontrolą ciśnienia tętniczego stwierdzono czynniki ryzyka sercowo-naczyniowego: u 78\% dyslipidemię (65\% hipercholesterolemię), u 68,3\% otyłość brzuszną, a 1/4 badanych paliła tyt6ń [8]. Badania populacyjne przeprowadzone w 26 krajach na całym świecie wśród 17092 pacjentów wskazują, że odsetek współwystępowania nadciśnienia tętniczego i dyslipidemii globalnie przekracza 50\%, a najwyższy odnotowuje się w Ameryce Północnej $[9,10]$.

Zarówno nadciśnienie tętnicze, jak i hipercholesterolemia niezależnie wpływają na ryzyko wystąpienia choroby wieńcowej. Według wytycznych Polskiego Towarzystwa Nadciśnienia Tętniczego (PTNT) nadciśnienie tętnicze jest najistotniejszym czynnikiem ryzyka przedwczesnych zgonów na świecie, a wartości ciśnienia tętniczego wykazują liniowy związek ze śmiertelnością i zapadalnością na choroby układu krążenia (zawał serca, udar mózgu, niewydolność serca, choroba tętnic obwodowych) oraz niewydolność nerek [11]. Autorzy II Deklaracji Sopockiej, opracowanej przez Sekcję Farmakoterapii Sercowo-Naczyniowej Polskiego Towarzystwa Kardiologicznego, podkreślają, że dyslipidemia jest nie tylko czynnikiem bardzo rozpowszechnionym, ale rów-

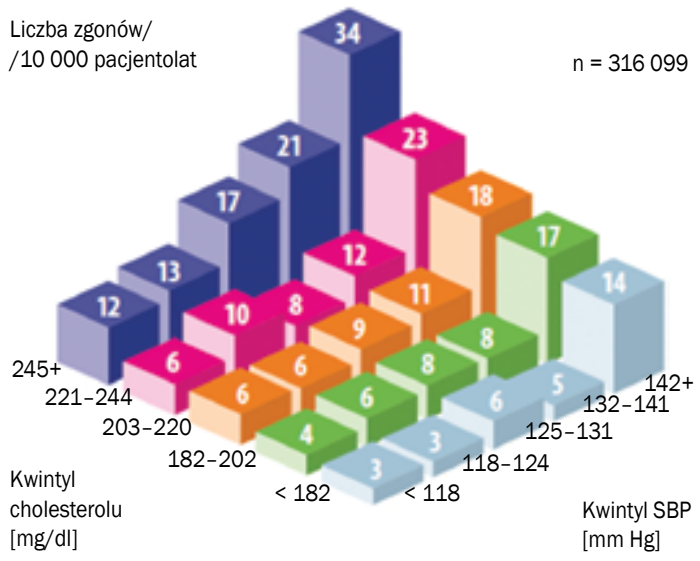

Rycina 1. Ryzyko sercowo-naczyniowe a wartość skurczowego ciśnienia tętniczego (SBP, systolic blood pressure) i stężenia cholesterolu całkowitego (opracowano na podstawie [14])

nież takim, który w największym stopniu wpływa na ryzyko przyszłych powikłań sercowo-naczyniowych [12]. Ryzyko sercowo-naczyniowe u chorych z nadciśnieniem tętniczym i hipercholesterolemią jest istotnie wzmożone w porównaniu z chorymi cechującymi się pojedynczymi czynnikami ryzyka. Jackson i wsp. [13] oszacowali 5-letnie ryzyko wystąpienia incydentu sercowo-naczyniowego zależnie od wartości skurczowego ciśnienia tętniczego (SBP, systolic blood pressure) w grupie pacjentów z prawidłowym stężeniem cholesterolu w porównaniu z osobami, u których wartości TC przekraczały $7 \mathrm{mmol} / \mathrm{l}(270 \mathrm{mg} / \mathrm{dl})$. Wykazano, że u osób z hipercholesterolemią ryzyko incydentów sercowo-naczyniowych było 2-krotnie wyższe niż u pacjentów z prawidłowym stężeniem cholesterolu i ryzyko to zwiększało się także wraz ze wzrostem wartości SBP o każde $10 \mathrm{~mm} \mathrm{Hg}$. Pacjenci z nadciśnieniem tętniczym i dyslipidemią są obciążeni najwyższym ryzykiem sercowo-naczyniowym 4-krotnie wyższym niż u osób z prawidłowym ciśnieniem i prawidłowym stężeniem cholesterolu (ryc. 1) [14].

\section{Cele terapii hipotensyjnej \\ i hipolipemizującej}

Autorzy wytycznych PTNT podkreślają konieczność równoległego leczenia nadciśnienia tętniczego i hipercholesterolemii, a ocena globalnego ryzyka sercowo-naczyniowego jest konieczna do obrania właściwej strategii leczenia chorego z nadciśnieniem tętniczym. Jednoczesne leczenie hipotensyjne i stosowanie statyny jest wskazane także u osób z nadciśnieniem tętniczym obciążonych czynnikami ryzyka sercowo-naczyniowego oraz ze współistniejącą chorobą niedokrwienną serca, przewlekłą chorobą nerek i cukrzycą [11].

W badaniu obejmującym 7735 mężczyzn oceniano najskuteczniejszą metodę kontroli czynników ryzyka sercowo- 


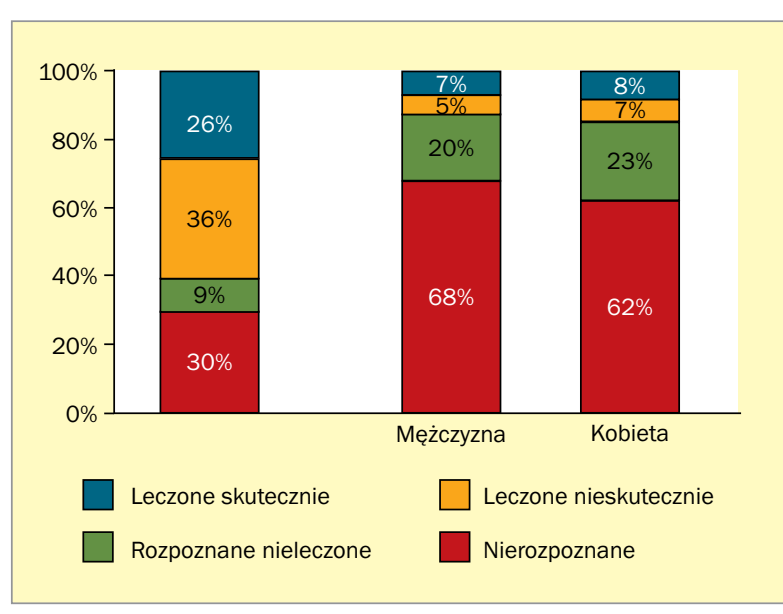

Rycina 2. Stopień kontroli nadciśnienia tętniczego i dyslipidemii w badaniu NATPOL 2011 (opracowano na podstawie [4])

-naczyniowego. Stosowanie jedynie leczenia hipotensyjnego wiązało się z obniżeniem ryzyka sercowo-naczyniowego o 10\%, stosowanie jedynie leczenia hipolipemizującego także prowadziło do redukcji ryzyka sercowo-naczyniowego o 10\%. Natomiast jednoczesna kontrola zarówno stężenia cholesterolu, jak i wartości ciśnienia tętniczego powodowała obniżenie ryzyka zgonów sercowo-naczyniowych aż o 41\% [15]. Uzasadnione jest więc dążenie do optymalizacji leczenia pacjentów polegającej na osiąganiu wartości docelowych w leczeniu hipercholesterolemii i nadciśnienia tętniczego.

W populacji ogólnej jedynie u 14,3\% pacjentów kontrola zarówno nadciśnienia tętniczego, jak i hipercholesterolemii jest zadowalająca [16]. Stopień kontroli nadciśnienia w Polsce od lat jest niedostateczny. Bardzo niską, bo tylko 12-procentową skuteczność leczenia nadciśnienia, odnotowano w badaniu NATPOL w 2002 roku [17]. Według wyników badania NATPOL 2011 odsetek chorych ze skutecznie leczonym nadciśnieniem tętniczym zwiększył się 2-krotnie i obecnie wynosi $26 \%$ [4].

Podobnie chorzy z zaburzeniami gospodarki lipidowej nie są dostatecznie skutecznie leczeni, a często nie są świadomi swojej choroby. W grupie osób z hipercholesterolemią 58,7\% (61,5\% mężczyzn i 56,0\% kobiet) nie było świadomych jej obecności, 22,0\% (21,0\% mężczyzn i 24,5\% kobiet) wiedziało o niej, ale nie było leczonych, 8,1\% (7,7\% mężczyzn i 8,5\% kobiet) było leczonych nieskutecznie, a tylko 10,9\% (10,7\% mężczyzn i 11,0\% kobiet) osiągało wartości docelowe [7] (ryc. 2).

\section{Niedostateczna kontrola nadciśnienia tętniczego i hipercholesterolemii - jakie są przyczyny? Jak poprawić kontrolę?}

Najczęstszą przyczyną nieskuteczności leczenia nadciśnienia tętniczego oraz hipercholesterolemii jest niestosowanie się do zaleceń lekarskich przez pacjentów oraz zalecanie niedostatecznie skutecznych terapii przez lekarzy. Oszacowano, że w 3. miesiącu po wdrożeniu leczenia hipotensyjnego i hipolipemizującego odsetek chorych przestrzegających zaleceń lekarskich wynosił 44,7\%, a 6 miesięcy po rozpoczęciu leczenia tylko 1 na 3 pacjentów przyjmował zarówno lek na nadciśnienie tętnicze, jak i statynę [10].

Chowdhury i wsp. [18] w metaanalizie obejmującej dane około 2 milionów osób wykazali, że znaczna część (43\%) nie przestrzegała odpowiednio zaleceń dotyczących przyjmowania leków w terapii schorzeń układu sercowo-naczyniowego. Dowiedziono, że właściwe przestrzeganie zaleceń lekarskich mogłoby zmniejszyć ryzyko wystąpienia chorób układu krążenia o 20\% i ryzyko śmiertelności całkowitej o 38\%. Zadowalające przestrzeganie zaleceń w odniesieniu do statyn wiązało się z redukcją ryzyka chorób układu krążenia o 15\% i śmiertelności całkowitej o 45\%. Należyte przestrzeganie zaleceń dotyczących leków hipotensyjnych powodowało obniżenie ryzyka wystąpienia chorób układu krążenia o 19\% ( $n=552$ 143) i śmiertelności całkowitej o 29\% ( $n=205$ 598).

Stosowanie terapii skojarzonej i leków złożonych w leczeniu schorzeń układu sercowo-naczyniowego, a zarazem uproszczenie schematu terapii, istotnie poprawia przestrzeganie zaleceń lekarskich, a tym samym skuteczność leczenia nadciśnienia tętniczego i dyslipidemii. Na podstawie danych z rejestru Cardiovascular Research Network oceniono częstość stosowania oraz skuteczność politerapii, w tym także terapii złożonej, u chorych z nowo rozpoznanym nadciśnieniem tętniczym. Analizą objęto dane 161585 osób z nowo rozpoznanym nadciśnieniem tętniczym między 2002 a 2007 rokiem, u których włączano złożone leczenie hipotensyjne. U badanych z nowo rozpoznanym nadciśnieniem tętniczym, u których rozpoczęto leczenie złożone, zaobserwowano zmniejszenie liczby osób z nadciśnieniem tętniczym 2. stopnia do 40\% badanych w 2007 roku w porównaniu z 59\% badanych w 2002 roku ( $p<0,001)$. W grupie osób leczonych za pomocą skojarzonej terapii hipotensyjnej stwierdzono obniżenie wartości średniego SBP z 158,1 mm Hg (2002 r.) do 152,3 mm Hg (2007 r.). Podobnie obserwowano obniżenie średniego rozkurczowego ciśnienia tętniczego (DBP, diastolic blood pressure) z 91,3 mm Hg (2002 r.) do 89,6 mm Hg (2007 r.). Początkowe włączenie terapii skojarzonej wiązało się z większym prawdopodobieństwem dobrej kontroli ciśnienia tętniczego po roku leczenia (iloraz szans [OR, odds ratio] w porównaniu z monoterapią: 1,16; 95-proc. przedział ufności [Cl, confidence interval] 1,12-1,20; $p<$ $<0,001)$. Zarówno przepisanie jednego leku złożonego (OR 1,16; 95\% Cl 1,12-1,20; p < 0,001), jak i dwóch leków hipotensyjnych w skojarzeniu (OR 1,14; 95\% Cl 1,06-1,23; $p<0,001)$ pozwalało na lepszą kontrolę hipotensyjną niż monoterapia [19]. W obejmującej 7047 chorych metaanalizie badań z randomizacją, w których stosowano preparaty złożone, tj. pojedyncze tabletki o różnym składzie i dawko- 
waniu (wszystkie zawierały statynę i co najmniej jeden lek hipotensyjny), wykazano, że terapia preparatem złożonym poprawia przestrzeganie zaleceń o 33\% w porównaniu ze strategią stosowania wielu leków [20].

\section{Perindopril i amlodipina - skuteczność w terapii hipotensyjnej}

W terapii złożonej nadciśnienia tętniczego i dyslipidemii należy wybierać leki zawierające substancje o udowodnionym mechanizmie oraz synergii działania. Spośród leków hipotensyjnych najczęściej stosowaną grupą są inhibitory konwertazy angiotensyny (ACE, angiotensin-converting enzyme), ze względu na ich wysoką skuteczność oraz działanie plejotropowe. Obecnie inhibitory ACE uznaje się za leki pierwszego wyboru w leczeniu nadciśnienia tętniczego z chorobami współistniejącymi, takimi jak: przerost lewej komory serca, choroba niedokrwienna serca, niewydolność serca, miażdżyca obwodowa, zespół metaboliczny, cukrzyca, przewlekła choroba nerek. Antagonistów wapnia natomiast zaleca się jako leki pierwszego wyboru u chorych z nadciśnieniem tętniczym i współistniejącą miażdżycą obwodową, chorobami płucnymi, a także u chorych z izolowanym nadciśnieniem skurczowym i u pacjentów w podeszłym wieku.

W badaniu ASCOT-BPLA (Anglo-Scandinavian Cardiac Outcomes Trial-Blood Pressure Lowering Arm) wykazano skuteczność hipotensyjną terapii skojarzonej perindoprilem z amlodipiną. Była to wieloośrodkowa, prospektywna, kontrolowana, randomizowana próba kliniczna obejmującą 19257 chorych na nadciśnienie tętnicze. U badanych występowały co najmniej trzy inne, oprócz nadciśnienia tętniczego, czynniki ryzyka choroby niedokrwiennej serca. W jednej grupie chorym podawano amlodipinę w dawce 5-10 mg i dodatkowo, w razie potrzeby, perindopril w dawce 4-8 mg, a w drugiej grupie - atenolol 50-100 mg i dodatkowo, w razie potrzeby, diuretyk tiazydowy (bendroflumetiazyd) w dawce 1,25-2,5 mg. W grupie leczonej amlodipiną 85\% chorych przyjmowało dodatkowo perindopril, natomiast wśród otrzymujących atenolol 91\% chorych przyjmowało lek moczopędny. U wszystkich chorych uzyskano docelowe wartości ciśnienia tętniczego; średnie wartości ciśnienia były nieistotnie niższe w grupie chorych otrzymujących amlodipine/perindopril niż w grupie chorych leczonych atenolololem/diuretykiem tiazydowym (średnia różnica 2,7/1,9 mm Hg). Największą różnicę w zakresie wartości ciśnienia odnotowano w 3. miesiącu stosowania zaleconego leczenia (5,9/2,4 mm Hg) [21]. Badanie ASCOT-BPLA było pierwszym, w którym porównanie dotyczyło skojarzonej terapii hipotensyjnej, i zakończono je przedwcześnie, ponieważ w grupie chorych otrzymujących perindopril z amlodipiną obserwowano istotną redukcję częstości występowania punktów końcowych w porównaniu z chorymi leczonymi atenololem i diuretykiem. Z kolei w analizie post-hoc badania EUROPA (EURopean trial On reduction of cardiacevents with Perindopril in stable coronary Artery) oceniano wpływ stosowania skojarzonej terapii hipotensyjnej, złożonej z perindoprilu i amlodipiny, z terapią amlodipiną [22]. W ponad 4-letniej obserwacji stosowanie terapii skojarzonej wiązało się z 46-procentową redukcją ryzyka zgonu niezależnie od przyczyny oraz pierwotnego punktu końcowego badania (zgon sercowo-naczyniowy, zawał serca, nagłe zatrzymanie krążenia) o 35\%. Wykazano także 41-procentową redukcję ryzyka zgonu sercowo-naczyniowego, 54-procentowe obniżenie ryzyka hospitalizacji z powodu niewydolności serca oraz 28-procentowe zmniejszenie ryzyka zawału serca [22]. W badaniu SYMBIO, prospektywnym badaniu 4. fazy obejmującym 2132 pacjentów leczonych z powodu nadciśnienia tętniczego inhibitorem ACE i/lub antagonistą wapnia (najczęściej amlodipiną), dowiedziono, że połączenie perindoprilu i amlodipiny w preparacie złożonym znacznie obniżało ciśnienie tętnicze, niezależnie od wcześniej stosowanego leczenia [23]. W tym samym badaniu połączenie perindoprilu i amlodipiny znacznie obniżało ciśnienie tętnicze już w 1. miesiącu leczenia, niezależnie od stopnia nadciśnienia na początku badania [23] (ryc. 3).

\section{Atorwastatyna - skuteczność w terapii hipercholesterolemii}

Statyny są najczęściej wybieranymi lekami w terapii zaburzeń lipidowych i stanowią 91\% wszystkich leków hipolipemizujących przepisywanych w Polsce [12]. Dwie najskuteczniejsze statyny dostępne obecnie na polskim rynku to atorwastatyna oraz rosuwastatyna. Atorwastatynę

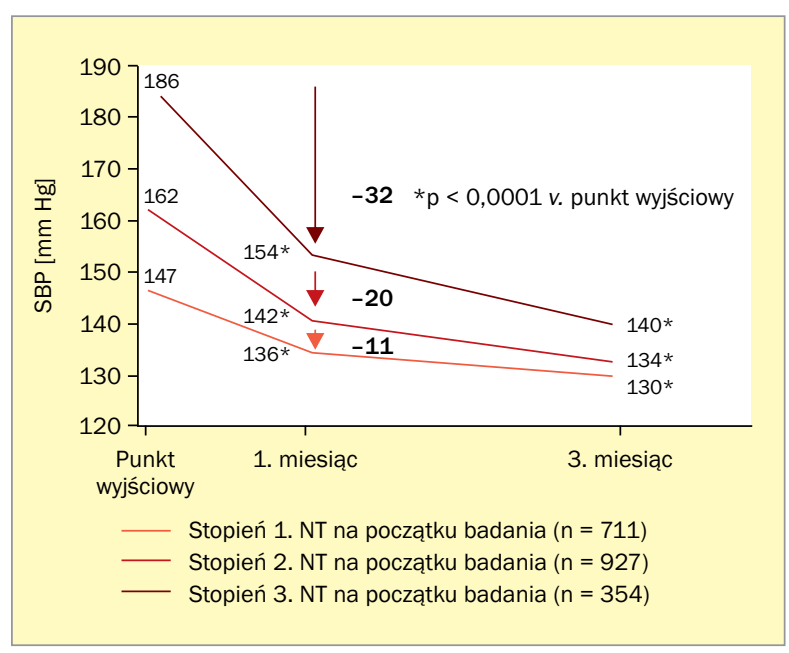

Rycina 3. Obniżenie wartości ciśnienia tętniczego u chorych leczonych preparatem złożonym perindopril/amlodipina (opracowano na podstawie [22]); SBP (systolic blood pressure) - skurczowe ciśnienie tętnicze 
przebadano w populacji pacjentów leczonych jednocześnie perindoprilem. W badaniu JCAD (Japanese Coronary Artery Disease Study) wykazano, że równoczesna blokada układu renina-angiotensyna-aldosteron (RAA) oraz stosowanie statyny u pacjentów z grupy wysokiego ryzyka sercowo-naczyniowego wiązała się z istotną redukcją częstości występowania incydentów sercowo-naczyniowych [24]. Zjawisko to można wytłumaczyć addytywnym, korzystnym wpływem na hamowanie reakcji zapalnej. W zalecaniu leków złożonych zawierających statynę oraz leki hipotensyjne istotny jest fakt, że atorwastatyna nie musi być stosowana wyłącznie w godzinach wieczornych. Koncepcja zalecania pacjentom stosowania statyn wyłącznie w godzinach wieczornych wynikała z farmakokinetyki leków starszej generacji. Nowoczesne statyny, takie jak atorwastatyna i rosuwastatyna, mogą być bezpiecznie stosowane w ciągu całej doby ze względu na długi okres półtrwania oraz obecność aktywnych metabolitów, nie ma zatem konieczności, by pacjent przyjmował preparatu złożony, zawierający nowoczesną statynę, wieczorem.

Synergizm działania perindoprilu, amlodipiny i atorwastatnyny u chorych z nadciśnieniem tętniczym i hipercholesterolemią

Synergia działania atorwastatynąy, perindoprilu i amlodipiny może wynikać z plejotropowego, pozalipidowego i pozahipotensyjnego działania każdego z wymienionych leków. Hamują one dysfunkcję śródbłonka, utlenianie LDL, proliferację i migrację komórek mięśni gładkich i degradację blaszki włóknisto-tłuszczowej, które razem przyczyniają się do hamowania tworzenia i zwiększonej stabilności już istniejącej blaszki miażdżycowej.

W grupie lipidowej badania ASCOT (Anglo-Scandinavian Cardiac Outcomes Trial) 10305 chorych ze stężeniem TC poniżej $6,5 \mathrm{mmol} / \mathrm{l}(250 \mathrm{mg} / \mathrm{dl})$ poddano randomizacji do grupy otrzymującej placebo lub atorwastatynę. W porównaniu z placebo atorwastatyna zmniejszała liczbę przypadków zawału serca niezakończonego zgonem lub zakończonej zgonem choroby wieńcowej o 53\% (współczynnik ryzyka [HR, hazard ratio] 0,47, Cl 0,32-0,69; p < 0,0001) wśród pacjentów przydzielonych do terapii opartej na perindoprilu i amlodipinie, natomiast w grupie pacjentów leczonych atenololem i tiazydem ograniczenie częstości występowania punktu końcowego wynosiło zaledwie 16\% (HR 0,84, Cl 0,60-1,17; $p=0,30$ ) (ryc. 4) [25].

Synergistyczny efekt działania statyn oraz perindoprilu i amlodipiny oceniono w badaniu PERSPECTIVA, do którego włączono 587 chorych z niekontrolowanym nadciśnieniem tętniczym i hipercholesterolemią [26]. Wśród badanych 226 chorych otrzymywało statynę, a 361 jej nie przyjmowało. Badanie trwało 60 dni, a wartości ciśnienia tętniczego monitorowano w jego 7., 15., 30. i 60. dniu. W 60. dobie badania docelowe wartości ciśnienia tętniczego stwierdzono u $64 \%$ badanych leczonych perindoprilem i amlodipiną oraz u $73 \%$ badanych leczonych perindoprolem, amlodipiną oraz statyną $(p<0,5)$. Możliwy addytywny efekt hipotensyjny amlodipiny i perindoprilu oraz statyny upatrywano we wpływie statyn na śródbłonek naczyniowy, a w szczególności działaniu wazodylatacyjnym.

Oprócz redukcji wartości ciśnienia tętniczego i protekcji sercowo-naczyniowej synergia między trzema molekułami - atorwastatyną, amlodipiną i perindoprilem - istotnie zwiększa tolerancję leczenia. Perindopril znacznie obniża ryzyko wystąpienia obrzęków wywoływanych przez amlodipinę. W badaniu z 3-miesięcznym okresem obserwacji, obejmującym 2132 pacjentów, połączenie perindoprilu i amlodipiny znacząco, bo o 58\% w porównaniu z monoterapią antagonistami wapnia, ograniczało wywołany amlodipiną obrzęk kostek. Perindopril zmniejsza obrzęki obwodowe spowodowane działaniem amlodipiny poprzez hamowanie układu RAA, osłabienie wywołanej amlodipiną aktywności odruchowej układu współczulnego oraz rozszerzenie naczyń pozawłośniczkowych [27].

\section{Podsumowanie}

Poprawa skuteczności leczenia nadciśnienia tętniczego oraz hipercholesterolemii jest istotnym celem w prewencji zdarzeń sercowo-naczyniowych. Nieprzestrzeganie zaleceń terapeutycznych to jedna z najistotniejszych przyczyn niedostatecznej kontroli nadciśnienia tętniczego i hipercholesterolemii. Stosowanie leków złożonych istotnie poprawia współpracę pacjenta z lekarzem. Lek zawierający perindopril, amlodipinę i atorwastatynę to skojarzenie skutecznych substancji, o udowodnionym działaniu klinicznym i wysokim profilu bezpieczeństwa. Synergistyczny efekt działania wymienionych substancji dodatkowo przemawia za stosowaniem omawianego leku złożonego w celu osiągnięcia docelowych wartości ciśnienia tętniczego i stężenia cholesterolu we krwi.

\section{Opis przypadku klinicznego}

Pacjent w wieku 65 lat, z wieloletnim wywiadem nadciśnienia tętniczego, został skierowany przez lekarza rodzinnego do poradni nadciśnienia tętniczego z powodu złej kontroli nadciśnienia. W wywiadzie stwierdzono:

- chorobę niedokrwienną serca - stan po zawale serca bez uniesienia odcinka ST i przezskórnej interwencji wieńcowej (PCl, perceutaneous coronary intervention) w obrębie gałęzi przedniej zstępującej (LAD, left anterior descending) w 2011 roku;

- hipercholesterolemię mieszaną (aktualne wyniki badań: stężenie TC $227 \mathrm{mg} / \mathrm{dl}$, stężenie cholesterolu frakcji LDL 156 mg/dl, stężenie cholesterolu frakcji HDL 
A

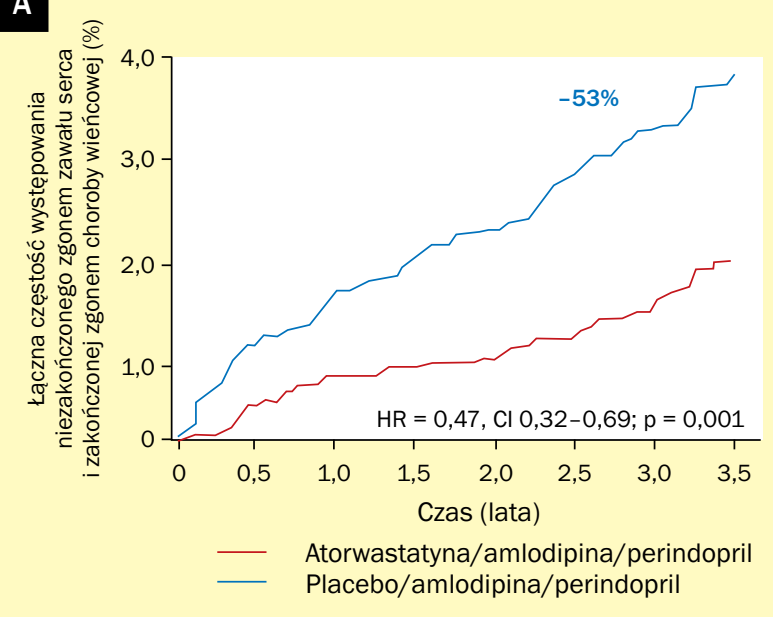

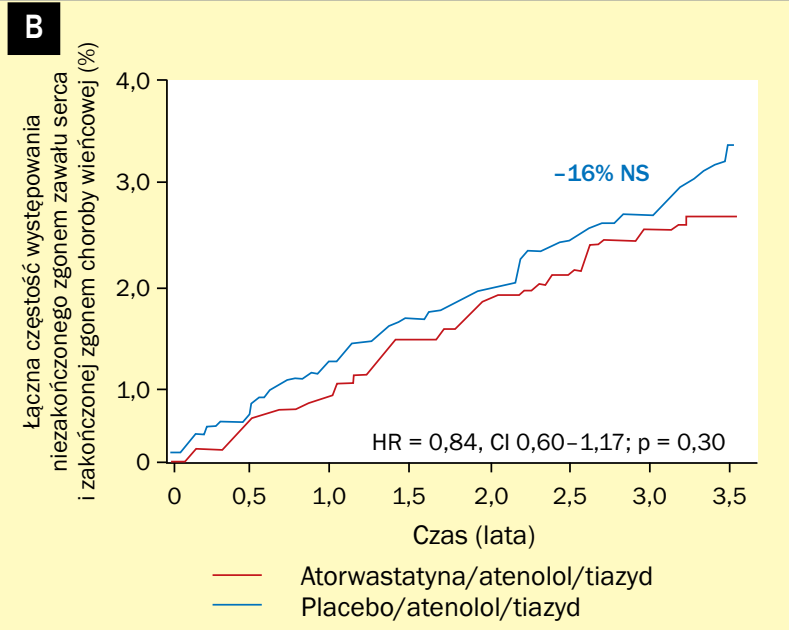

B Placebo/atenolol/tiazyd

Rycina 4A, B. Częstość występowania zawału serca niezakończonego zgonem lub zgonu z powodu choroby wieńcowej w badaniu ASCOT-LLA (Anglo-Scandinavian Cardiac Outcomes Trial - Lipid Lowering Arm) (opracowano na podstawie [24]); NS - nieznamienne statystycznie; HR (hazard ratio) - współczynnik ryzyka; $\mathrm{Cl}$ (confidence interval) - przedział ufności

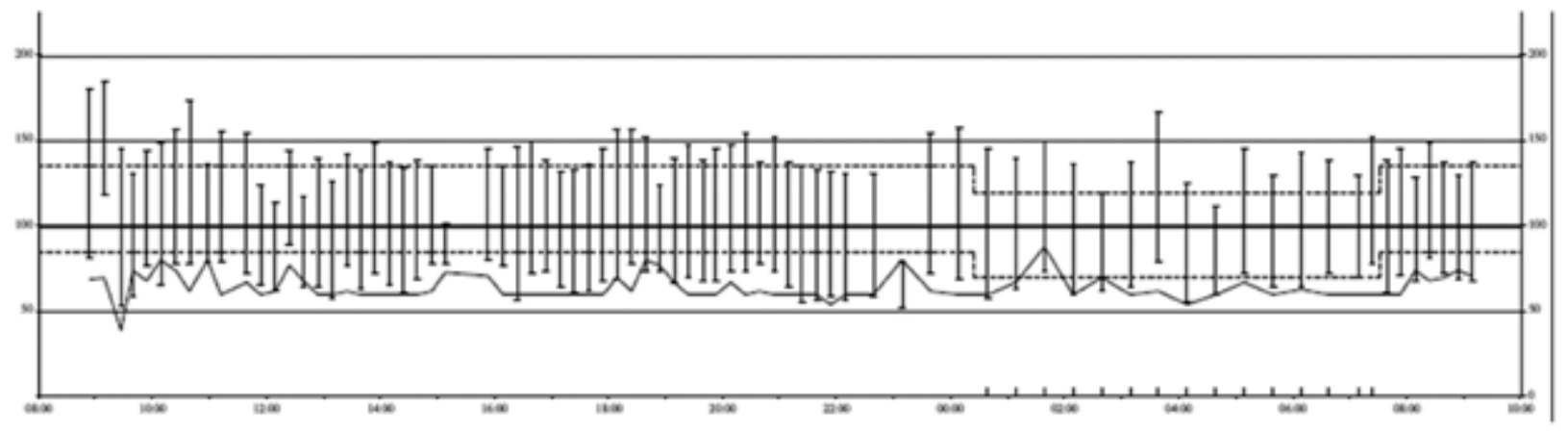

Rycina 5. Wykres wartości ciśnienia tętniczego w ciągu całej doby w trakcie nieskutecznej terapii (aparat GE Tonoport V)

Tabela 1. Wynik całodobowego monitorowania ciśnienia tętniczego w trakcie nieskutecznej terapii

\begin{tabular}{|c|c|c|c|c|c|c|c|}
\hline \multicolumn{8}{|c|}{ Czas trwania monitorowania: $24 \mathrm{~h} 17 \mathrm{~min}$} \\
\hline \multicolumn{4}{|c|}{ Okres snu: 00:15-07:30 } & \multicolumn{4}{|c|}{ Godzina wstania z łóżka: 07:30 } \\
\hline \multicolumn{8}{|c|}{ Liczba pomiarów poddawanych interpretacji: 77 z 77 (100\%) } \\
\hline \multicolumn{8}{|c|}{ Liczba interpretowanych pomiarów (łącznie/dzień/noc): 77/62/15 } \\
\hline & & SBP & DBP & & & SBP & DBP \\
\hline \multirow{3}{*}{$\begin{array}{l}\text { Średnia war- } \\
\text { tość BP } \\
{[\mathrm{mm} \mathrm{Hg}]}\end{array}$} & Cała doba & 140,1 & 69 & \multirow{3}{*}{$\begin{array}{l}\text { Minimalna wartość BP } \\
{[\mathrm{mm} \mathrm{Hg}]}\end{array}$} & & & \\
\hline & Czuwanie & 140,6 & 69,7 & & Czuwanie & 79 & 52 \\
\hline & Sen & 138,1 & 66,4 & & Sen & 112 & 55 \\
\hline \multirow{3}{*}{$\begin{array}{l}\text { Ładunek BP } \\
(\%)\end{array}$} & & & & \multirow{3}{*}{$\begin{array}{l}\text { Maksymalna wartość } \\
\text { BP }[\mathrm{mm} \mathrm{Hg}]\end{array}$} & & & \\
\hline & Czuwanie & 66,1 & 3,2 & & Czuwanie & 185 & 119 \\
\hline & Sen & 86,6 & 29 & & Sen & 167 & 79 \\
\hline \multirow{4}{*}{$\begin{array}{l}\text { Dobowy } \\
\text { profil BP }\end{array}$} & Nocny spadek BP (\%) & $-1,8$ & $-4,7$ & \multirow[t]{4}{*}{ Zmienność BP (SD) } & Cała doba & 15,5 & 9,8 \\
\hline & BP noc/BP dzień & 0,98 & 0,95 & & & & \\
\hline & \multirow{2}{*}{$\begin{array}{l}\text { Poranny wzrost BP } \\
{[\mathrm{mm} \mathrm{Hg}]}\end{array}$} & \multirow[t]{2}{*}{8} & \multirow[t]{2}{*}{9,7} & & Czuwanie & 15,9 & 10,2 \\
\hline & & & & & Sen & 13,2 & 7,1 \\
\hline
\end{tabular}

BP (blood pressure) - ciśnienie tętnicze; SBP (systolic blood pressure) - skurczowe ciśnienie tętnicze; DBP (diastolic blood pressure) - rozkurczowe ciśnienie tętnicze; SD (standard deviation) - odchylenie standardowe 


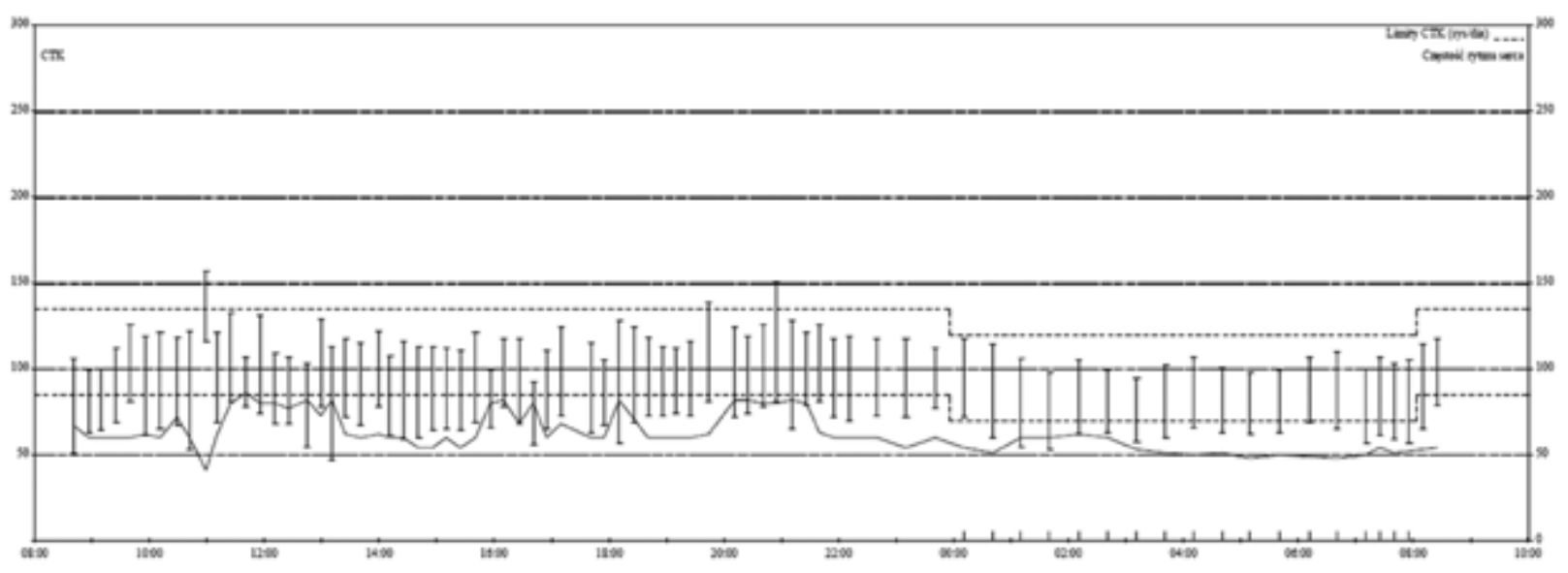

Rycina 6. Wykres wartości ciśnienia tętniczego w ciągu całej doby w trakcie skutecznej terapii lekiem złożonym (aparat GE Tonoport V)

$57 \mathrm{mg} / \mathrm{dl}$, stężenie triglicerydów [TG, triglycerides] $70 \mathrm{mg} / \mathrm{dl}$ );

- cukrzyce typu 2 leczoną lekami doustnymi;

- otyłość (wskaźnik masy ciała [BMI, body mass index] $33 \mathrm{~kg} / \mathrm{m}^{2}$, obwód brzucha $119 \mathrm{~cm}$ );

- kamice pęcherzyka żółciowego.

Chory przyjmował następujące leki: $5 \mathrm{mg}$ ramiprilu 2 razy/dobę, $40 \mathrm{mg}$ furosemidu raz/dobę rano, $25 \mathrm{mg}$ metoprololu 2 razy/dobe, $10 \mathrm{mg}$ atorwastatyny raz/dobe wieczorem. Zgłaszał bóle głowy w godzinach porannych z towarzyszącymi nudnościami. Stosował leki niesystematycznie; zwykle zapominał o ich przyjmowaniu w godzinach wieczornych. W pomiarach domowych większość wartości ciśnienia tętniczego przekraczała $135 / 85 \mathrm{~mm} \mathrm{Hg}$, maksymalne wartości ciśnienia wynosiły 170/95 mm Hg. Chory mierzył je nieregularnie, zwykle rano, przed zastosowaniem leków.

W związku z nieskuteczną terapią hipotensyjną zaplanowano zmianę leczenia hipotensyjnego po wykonaniu całodobowego monitorowania ciśnienia tętniczego (ABPM, ambulatory blood pressure measurement). Nadciśnienie tętnicze źle kontrolowane, a także u chorych ze wspótistniejącą cukrzyca, stanowi wskazanie do ABPM. W uzyskanym zapisie średnie wartości ciśnienia tętniczego oraz ładunek ciśnienia były nieprawidłowe w ciągu dnia i w nocy w przypadku SBP. Nocny spadek wartości SBP i DBP był niedostateczny. Obserwowano nadmierną zmienność SBP i DBP (ryc. 5, tab. 1).

W badaniu echokardiograficznym stwierdzono koncentryczny przerost mięśnia sercowego, wskaźnik masy lewej komory (LVMI, left ventricular mass index) wynosił $129 \mathrm{~g} / \mathrm{m}^{2}$, frakcja wyrzutowa lewej komory - $60 \%$, obserwowano zaburzoną czynność rozkurczową, a prędkość E' w części przegrodowej pierścienia mitralnego wynosiła $5,1 \mathrm{~cm} / \mathrm{s}$.
U omawianego chorego zalecono następującą farmakoterapię: lek złożony - atorwastatyna/perindopril/amlodipina $\mathrm{w}$ dawce 40/10/10 $\mathrm{mg}$ rano, indapamid $\mathrm{w}$ dawce $1,5 \mathrm{mg}$ rano. W zapisie ABPM wykonanym 6 tygodni po rozpoczęciu leczenia powyższym lekiem złożonym średnie wartości ciśnienia tętniczego oraz ładunek ciśnienia były prawidłowe w ciągu dnia i w nocy zarówno w przypadku SBP, jak i DBP. Nocny spadek wartości SBP i DBP był dostateczny (ryc. 5, tab. 2).

W kontrolnych pomiarach domowych ciśnienia tętniczego obserwowano stopniową normalizację jego wartości. Uzyskano również docelowe stężenie cholesterolu frakcji LDL wynoszące $65 \mathrm{mg} / \mathrm{dl}$, czyli osiągnięto cel terapii, jakim $u$ tego chorego jest obniżenie stężenia cholesterolu frakcji LDL poniżej $70 \mathrm{mg} / \mathrm{dl}$. Skojarzenie inhibitora ACE z antagonistą wapniowa stanowi rekomendowane skojarzenie dla chorych z nadciśnieniem tętniczym i zaburzeniami lipidowymi bądź cukrzycą, jest także optymalne u pacjenta z nadciśnieniem tętniczym i chorobą niedokrwienną serca. Perindopril to jeden z nielicznych inhibitorów ACE przebadanych w próbach klinicznych u osób z chorobą wieńcową, a długi okres jego działania sprawia, że jest preferowany w terapii nadciśnienia tętniczego i u opisanego chorego okazał się lepszym wyborem od ramiprilu. Znaczne uproszczenie terapii, podawanie wszystkich leków w godzinach porannych oraz trzech substancji w jednej tabletce okazało się istotnie przyczynić do osiągnięcia docelowych wartości ciśnienia tętniczego i cholesterolu.

\section{Konflikt interesów}

BWK - honoraria za wykłady dla firm: Egis, Krka, MSD, Mylan, Servier. 
Tabela 2. Wynik całodobowego monitorowania ciśnienia tętniczego w trakcie skutecznej terapii hipotensyjnej lekiem złożonym

\begin{tabular}{|c|c|c|c|c|c|c|c|}
\hline \multicolumn{8}{|c|}{ Czas trwania monitorowania: $24 \mathrm{~h} 00 \mathrm{~min}$} \\
\hline \multicolumn{4}{|c|}{ Okres snu: 23:50-08:00 } & \multicolumn{4}{|c|}{ Godzina wstania z łóżka: 08:00 } \\
\hline \multicolumn{8}{|c|}{ Liczba pomiarów poddawanych interpretacji: 78 z 78 (100\%) } \\
\hline \multicolumn{8}{|c|}{ Liczba interpretowanych pomiarów (łącznie/dzień/noc): 78/65/13 } \\
\hline & & SBP & DBP & & & SBP & DBP \\
\hline \multirow{3}{*}{$\begin{array}{l}\text { Średnia wartość } \\
\text { BP [mm Hg] }\end{array}$} & Cała doba & 114,3 & 67,6 & \multirow{3}{*}{$\begin{array}{l}\text { Minimalna wartość BP } \\
{[\mathrm{mm} \mathrm{Hg}]}\end{array}$} & & & \\
\hline & Czuwanie & 117,5 & 69,6 & & Czuwanie & 92 & 47 \\
\hline & Sen & 104 & 61,3 & & Sen & 95 & 53 \\
\hline \multirow[t]{3}{*}{ Ładunek BP (\%) } & & & & \multirow{3}{*}{$\begin{array}{l}\text { Maksymalna wartość } \\
\text { BP [mm Hg] }\end{array}$} & & & \\
\hline & Czuwanie & 5,1 & 1,7 & & Czuwanie & 157 & 116 \\
\hline & Sen & 0 & 5,5 & & Sen & 117 & 72 \\
\hline \multirow[t]{3}{*}{ Dobowy profil BP } & $\begin{array}{l}\text { Nocny spadek BP (\%) } \\
\text { BP noc/BP dzień }\end{array}$ & $\begin{array}{c}-11,5 \\
0,89 \\
\end{array}$ & $\begin{array}{c}-11,9 \\
0,88 \\
\end{array}$ & \multirow[t]{3}{*}{ Zmienność BP (SD) } & & & \\
\hline & \multirow{2}{*}{$\begin{array}{l}\text { Poranny wzrost BP } \\
\text { [mm Hg] }\end{array}$} & \multirow[t]{2}{*}{13,3} & \multirow[t]{2}{*}{14} & & Czuwanie & 11,1 & 10,1 \\
\hline & & & & & Sen & 5,6 & 4,7 \\
\hline
\end{tabular}

BP (blood pressure) - ciśnienie tętnicze; SBP (systolic blood pressure) - skurczowe ciśnienie tętnicze; DBP (diastolic blood pressure) - rozkurczowe ciśnienie tętnicze; SD (standard deviation) - odchylenie standardowe

\section{Abstract}

Arterial hypertension and dyslipidemia are the most common cardiovascular risk factors that often coexist. The effectiveness of their treatment is still unsatisfactory. The use of combination antihypertensive and hypolipemic therapy improves outcomes for the treatment of arterial hypertension and hypercholesterolaemia.

Key words: hypertension, dyslipidemia, combination therapy

Folia Cardiologica 2017; 12, 3: 262-270

\section{Piśmiennictwo}

1. Sulicka J, Fornal M, Gryglewska B, et al. Selected cardiovascular risk factors in primary care patients. Arterial Hypertens. 2006; 10: 370-376.

2. Roger VL, Go AS, Lloyd-Jones DM, et al. American Heart Association Statistics Committee and Stroke Statistics Subcommittee, American Heart Association Statistics Committee and Stroke Statistics Subcommittee. Heart disease and stroke statistics - 2011 update: a report from the American Heart Association. Circulation. 2011; 123(4): e18-e209, doi: 10.1161/CIR.0b013e3182009701, indexed in Pubmed: 21160056.

3. Williams B, Poulter NR, Brown MJ, et al. British Hypertension Society. Guidelines for management of hypertension: report of the fourth working party of the British Hypertension Society, 2004 - BHS IV. J Hum Hypertens. 2004; 18(3): 139-185, doi: 10.1038/sj.jhh.1001683, indexed in Pubmed: 14973512.

4. Zdrojewski T, Bandosz P, Rutkowski M, et al. Rozpowszechnienie, wykrywanie i skuteczność leczenia nadciśnienia tętniczego w Polsce - wyniki badania NATPOL 2011. Nadciś Tętn. 2014; 18: 116-117.

5. Tykarski A, Posadzy-Małaczyńska A, Wyrzykowski B, et al. Rozpowszechnienie nadciśnienia tętniczego oraz skuteczność jego leczenia u dorosłych mieszkańców naszego kraju. Wyniki programu WOBASz. Kardiol Pol. 2005; 63(supl. 4).
6. Ford ES, Mokdad AH, Giles WH, et al. Serum total cholesterol concentrations and awareness, treatment, and control of hypercholesterolemia among US adults: findings from the National Health and Nutrition Examination Survey, 1999 to 2000. Circulation. 2003; 107(17): 2185-2189, doi: 10.1161/01.CIR.0000066320.27195.B4, indexed in Pubmed: 12719276.

7. Scheidt-Nave CC, Busch MA, Knopf H, et al. [Prevalence of dyslipidemia among adults in Germany: results of the German Health Interview and Examination Survey for Adults (DEGS 1)]. Bundesgesundheitsblatt Gesundheitsforschung Gesundheitsschutz. 2013; 56(5-6): 661-667, doi: 10.1007/s00103-013-1670-0, indexed in Pubmed: 23703484.

8. Zdrojewski T, Solnica B, Cybulska B, et al. Rozpowszechnienie zaburzeń lipidowych w Polsce. Wyniki badania NATPOL 2011. Kardiol Pol. 2016; 74(3): 213-223, doi: 10.5603/kp.2016.0029.

9. Thoenes M, Bramlage P, Zhong S, et al. Hypertension control and cardiometabolic risk: a regional perspective. Cardiol Res Pract. 2012; 2012: 925046, doi: 10.1155/2012/925046, indexed in Pubmed: 22242212.

10. Chapman RH, Benner JS, Petrilla AA, et al. Predictors of adherence with antihypertensive and lipid-lowering therapy. Arch Intern Med. 
2005; 165(10): 1147-1152, doi: 10.1001/archinte.165.10.1147, indexed in Pubmed: 15911728.

11. Tykarski A, Narkiewicz K, Gaciong Z, et al. Zasady postępowania w nadciśnieniu tętniczym - 2015 rok. Wytyczne Polskiego Towarzystwa Nadciśnienia Tętniczego. Nadciś Tętn Prakt. 2015; 1(1): 1-70.

12. Wożakowska-Kapłon B, Filipiak K, Mamcarz A, et al. Aktualne problemy terapii dyslipidemii w Polsce - II Deklaracja Sopocka. Stanowisko grupy ekspertów wsparte przez Sekcję Farmakoterapii Sercowo-Naczyniowej Polskiego Towarzystwa Kardiologicznego. Kardiol Pol. 2014; 72(9): 847-853, doi: 10.5603/kp.2014.0182.

13. Jackson R, Lawes CM, Bennett DA, et al. Treatment with drugs to lower blood pressure and blood cholesterol based on an individual's absolute cardiovascular risk. Lancet. 2005; 365(9457): 434-441, indexed in Pubmed: 10170463.

14. Ferdinand KC. Primary prevention trials: lessons learned about treating high-risk patients with dyslipidemia without known cardiovascular disease. Curr Med Res Opin. 2005; 21: 1091-1097, doi: 10.1185/030079905X50552, indexed in Pubmed: 16004678.

15. Emberson J, Whincup P, Morris R, et al. Evaluating the impact of population and high-risk strategies for the primary prevention of cardiovascular disease. Eur Heart J. 2004; 25(6): 484-491, doi: 10.1016/j. ehj.2003.11.012, indexed in Pubmed: 15039128.

16. Welch V, Tang SSK. Treatment and control of BP and lipids in patients with hypertension and additional risk factors. Am J Cardiovasc Drugs. 2007; 7(5): 381-389, indexed in Pubmed: 17953476.

17. Zdrojewski T, Bandosz P, Szpakowski P. Ocena wybranych problemów dotyczących rozpowszechnienia i terapii nadciśnienia tętniczego w Polsce na podstawie badania NATPOL-PLUS. In: Postępy w nefrologii i nadciśnieniu tętniczym. Vol. II. Medycyna Praktyczna, Kraków 2002: 11-15.

18. Chowdhury R, Khan H, Heydon E, et al. Adherence to cardiovascular therapy: a meta-analysis of prevalence and clinical consequences. Eur Heart J. 2013; 34(38): 2940-2948, doi: 10.1093/eurheartj/eht295, indexed in Pubmed: 23907142.

19. Byrd JB, Zeng C, Tavel HM, et al. Combination therapy as initial treatment for newly diagnosed hypertension. Am Heart J. 2011; 162(2): 340-346, doi: 10.1016/j.ahj.2011.05.010, indexed in Pubmed: 21835296.

20. de Cates AN, Farr MR, Wright N, et al. Fixed-dose combination therapy for the prevention of cardiovascular disease. Cochrane Database Syst Rev. 2014(4): CD009868, doi: 10.1002/14651858.CD009868.pub2, indexed in Pubmed: 24737108.
21. Dahlöf B, Sever PS, Poulter NR, et al. Prevention of cardiovascular events with an antihypertensive regimen of amlodipine adding perindopril as required versus atenolol adding bendroflumethiazide as required, in the Anglo-Scandinavian Cardiac Outcomes Trial-Blood Pressure Lowering Arm (ASCOT-BPLA): a multicentre randomised controlled trial. Lancet. 2005; 366(9489): 895-906, doi: 10.1016/ /S0140-6736(05)67185-1, indexed in Pubmed: 16154016.

22. Bertrand ME, Ferrari R, Remme WJ, et al. EUROPA Investigators. Clinical synergy of perindopril and calcium-channel blocker in the prevention of cardiac events and mortality in patients with coronary artery disease. Post hoc analysis of the EUROPA study. Am Heart J. 2010; 159(5): 795-802, doi: 10.1016/j.ahj.2009.12.042, indexed in Pubmed: 20435188.

23. Hatala R, Pella D, Hatalová K, et al. Optimization of blood pressure treatment with fixed-combination perindopril/amlodipine in patients with arterial hypertension. Clin Drug Investig. 2012; 32(9): 603-612, doi: 10.2165/11634530-000000000-00000, indexed in Pubmed: 22877321.

24. Fujita M, Yamazaki T, Hayashi D, et al. JCAD Study Investigators. Comparison of cardiovascular events in patients with angiographically documented coronary narrowing with combined reninangiotensin system inhibitor plus statin versus renin-angiotensin system inhibitor alone versus statin alone (from the Japanese Coronary Artery Disease Study). Am J Cardiol. 2007; 100(12): 1750-1753, doi: 10.1016/j.amjcard.2007.07.025, indexed in Pubmed: 18082520.

25. Sever P, Dahlöf B, Poulter N, et al. ASCOT Steering Committee Members. Potential synergy between lipid-lowering and blood-pressure-lowering in the Anglo-Scandinavian Cardiac Outcomes Trial. Eur Heart J. 2006; 27(24): 2982-2988, doi: 10.1093/eurheartj/ehl403, indexed in Pubmed: 17145722.

26. Sirenko Y, Radchenko G. PERSPECTIVA Study Group. Impact of Statin Therapy on the Blood Pressure-Lowering Efficacy of a Single-Pill Perindopril/Amlodipine Combination in Hypertensive Patients with Hypercholesterolemia. High Blood Press Cardiovasc Prev. 2017; 24(1): 85-93, doi: 10.1007/s40292-017-0184-5, indexed in Pubmed: 28150140.

27. Makani H, Bangalore S, Romero J, et al. Effect of renin-angiotensin system blockade on calcium channel blocker-associated peripheral edema. Am J Med. 2011; 124(2): 128-135, doi: 10.1016/j.amjmed. 2010.08.007, indexed in Pubmed: 21295192. 